OPEN ACCESS

Edited by:

Zaleha Abdullah Mahdy,

National University of

Malaysia, Malaysia

Reviewed by:

Vallikannu Narayanan,

University of Malaya, Malaysia

Shuhaila Ahmad,

National University of

Malaysia, Malaysia

*Correspondence:

Xiuhua Yang

xhyang@cmu.edu.cn

Specialty section:

This article was submitted to

Obstetrics and Gynecological Surgery,

a section of the journal

Frontiers in Medicine

Received: 11 November 2021

Accepted: 10 February 2022

Published: 03 March 2022

Citation:

Tian Y and Yang X (2022) A Review of

Roles of Uterine Artery Doppler in

Pregnancy Complications.

Front. Med. 9:813343.

doi: 10.3389/fmed.2022.813343

\section{A Review of Roles of Uterine Artery Doppler in Pregnancy Complications}

\author{
Yingying Tian and Xiuhua Yang* \\ Department of Obstetrics, The First Hospital of China Medical University, Shenyang, China
}

The invasion of trophoblasts into the uterine decidua and decidual vessels is critical for the formation of placenta. The defects of placentation are related to the etiologies of preeclampsia (PE), fetal growth restriction (FGR), and small-for-gestational age (SGA) neonates. It is possible to predict significant vascular events during pregnancy through uterine artery Doppler (UAD). From the implantation stage to the end of pregnancy, detecting changes in uterine and placental blood vessels can provide a favorable diagnostic instrument for pregnancy complications. This review aims to collect literature about the roles of UAD in pregnancy complications. We consider all relevant articles in English from January 1, 1983 to October 30, 2021. Predicting pregnancy complications in advance allows practitioners to carry out timely interventions to avoid or lessen the harm to mothers and neonates. Administering low-dose aspirin daily before 16 weeks of pregnancy can significantly reduce the incidence of pregnancy complications. From early pregnancy to late pregnancy, UAD can combine with other maternal factors, biochemical indicators, and fetal measurement data to identify high-risk population. The identification of high-risk groups can also lessen maternal mortality. Besides, through moderate risk stratification, stringent monitoring for high-risk pregnant women can be implemented, decreasing the incidence of adversities.

\footnotetext{
Keywords: uterine artery, pregnancy, recurrent pregnancy loss, preeclampsia, fetal growth restriction, stillbirth, preterm, twin pregnancy
}

\section{INTRODUCTION}

The invasion of trophoblasts into the uterine decidua and decidual vessels is critical for the formation of placenta. Nominal blood circulation in the maternal uterine artery is conducive for a healthy intrauterine environment and for sustaining the functionality of the placenta, which ensures the growth of the fetus. It is primarily due to two reasons. First, the maternal blood brings nutrients and carries away the residues. Second, the blood flow in uterine artery affects the oxygen delivered to the maternal-fetal interface. The formation of uteroplacental blood vessels goes through two principal stages. In the first stage occurring before 12 weeks after fertilization, spiral arteries invade the boundary between the decidua and myometrium (1). The second stage occurs from 12 to 16 weeks into the pregnancy, when the spiral arteries invade the interior of the myometrium (2). Accordingly, the two-stage recasting process transforms the narrow myometrial spiral arteries into uterine placental vessels with low resistance. The defects of placentation are related to the etiologies of preeclampsia (PE), fetal growth restriction (FGR), and small-for-gestational age (SGA) neonates $(3,4)$.

It is possible to predict significant vascular events during pregnancy through uterine artery Doppler (UAD). From the implantation stage to the end of pregnancy, detecting changes in 
uterine and placental blood vessels can provide a favorable diagnostic instrument for pregnancy complications (5). Quantitative parameters can identify abnormal uterine artery recasting and decreased uterine artery blood flow, and find highrisk pregnant women who are likely to face adverse pregnancy outcomes. Uterine placental vascular impedance gradually declines during angiogenesis and stabilizes after 24 gestational weeks (2). The reduction of placental blood perfusion may occur again in the successive pregnancy (6). The pulsatility index (PI), resistance index (RI), systolic/diastolic (S/D) ratio, and the appearance of an early diastolic notch are common indicators to evaluate uterine artery blood flow $(1,7)$.

Admittedly, some studies have found that the abnormal uterine artery blood flow was related to the onset of pregnancy complications $(2,8)$. However, other studies did not confirm this association $(9,10)$. This review aims to collect literature about the roles of UAD in pregnancy complications. Two independent researchers searched PUBMED for articles with the following medical subject headings (MeSHs): "uterine artery," "blood flow," "pregnant," "recurrent pregnancy loss," "preeclampsia," "fetal growth restriction," "stillbirth," "preterm," or "twin pregnancy." We consider all relevant articles in English from January 1, 1983 to October 30, 2021.

\section{UAD IN A NORMAL PREGNANCY}

The uterine artery blood flow begins to increase in the luteal phase and peaks in the window of implantation (11). Past researches have confirmed the reference range of uterine artery parameters in healthy pregnant women from 11 to 41 weeks of pregnancy in different countries (Table 1) (12-21). One study measured the uterine artery blood flow at 24, 28-30, and 34 weeks, respectively (22). It was found that $49 \%$ of patients with abnormal blood flow at 24 weeks returned to normal at 34 weeks (22). In a normal pregnancy, there is no significant change in the uterine artery impedance from 24 weeks to the end of pregnancy (23). Besides, maternal race, heart rate, and antihypertensive drug usage influence uterine artery impedance (1). If maternal body mass index (BMI) is too high, the uterine artery PI (UtA-PI) will be less (1). Besides, UtA-PI of the placental side is lower than that of the non-placental side (24).

"Notching" is a relatively common characteristic that appears during the early stages of $46-64 \%$ of normal pregnancies (1). A diastolic notch is a reduction in the maximum diastolic blood flow by at least $50 \mathrm{~cm} / \mathrm{s}$ after 20 gestational weeks (25). However, most reports adopt subjective diagnostic criteria. Like UtA-PI, the incidence of "notch" decreases after 24 weeks of pregnancy and remains stable. Continuous early diastolic notch is a manifestation of abnormal uterine vascular tension, and poor placentation may increase uterine artery impedance (26). Considering the low repeatability of uterine artery notch, UtAPI is preferred as an indicator of vascular impedance with its objective detection.

Transabdominal or transvaginal ultrasound can both detect UAD. During the testing process, UAD needs to be checked according to the standard procedure to obtain accurate results.

TABLE 1 | Studies on uterine artery Doppler in normal pregnant women.

\begin{tabular}{|c|c|c|c|c|c|}
\hline Authors & Population & $\begin{array}{l}\text { Gestational } \\
\text { weeks }\end{array}$ & Research type & $\begin{array}{l}\text { Number of } \\
\text { subjects }\end{array}$ & Results \\
\hline $\begin{array}{l}\text { Kurmanavicius et al. } \\
1997 \text { (12) }\end{array}$ & Swiss & $24-42$ & $\begin{array}{l}\text { Cross-sectional } \\
\text { study }\end{array}$ & 1675 & The 95th percentile of RI fluctuated between 0.56 and 0.61 . \\
\hline $\begin{array}{l}\text { Dejthevaporn et al. } \\
2002(13)\end{array}$ & $\begin{array}{l}\text { Chinese } \\
\text { Taiwanese }\end{array}$ & $22-28$ & $\begin{array}{l}\text { Cross-sectional } \\
\text { study }\end{array}$ & 265 & Mean $\mathrm{Pl}:<0.9,95 \% \mathrm{Cl}$ of $\mathrm{Pl}:<1.0$ \\
\hline $\begin{array}{l}\text { Mäkikallio et al. } 2004 \\
\text { (14) }\end{array}$ & Finnish & $5-10$ & Longitudinal study & 16 & $\begin{array}{l}\text { There was no significant change in PI at } 5-8 \text { weeks. PI decreased significantly } \\
\text { from } 8 \text { to } 10 \text { weeks. }\end{array}$ \\
\hline Gómez et al. 2008 (15) & Spanish & $11-41$ & $\begin{array}{l}\text { Cross-Sectional } \\
\text { study }\end{array}$ & 620 & $\begin{array}{l}\text { PI reduced significantly from } 11 \text { weeks (mean PI: } 1.79 \text {; 95th centile: } 2.70 \text { ) to } 34 \\
\text { weeks (mean PI: } 0.70 ; 95 \text { th centile: } 0.99 \text { ). Between } 34 \text { and } 41 \text { weeks, the value } \\
\text { of PI was relatively stable (mean } \mathrm{PI}: 0.65 ; 95 \text { th centile: } 0.89 \text { ). }\end{array}$ \\
\hline Liao et al. 2009 (16) & Brazilian & $11-14 ; 20-25$ & $\begin{array}{l}\text { Longitudinal } \\
\text { prospective study }\end{array}$ & 344 & $\begin{array}{l}\text { In the first trimester, the 50th and } 95 \text { th percentile of } \mathrm{PI} \text { were } 1.69 \text { and } 2.48 \text {, } \\
\text { respectively. In the second trimester, the 50th and 95th percentile of PI were } \\
1.03 \text { and } 1.57 \text {, respectively. }\end{array}$ \\
\hline Flo et al. 2011 (17) & Norwegian & $22-40$ & Longitudinal study & 53 & Mean PI: 0.79-0.56 Mean RI: 0.51-0.40 Mean S/D: 2.0-1.7 \\
\hline $\begin{array}{l}\text { Bahlmann et al. } 2012 \\
\text { (18) }\end{array}$ & German & $18-42$ & $\begin{array}{l}\text { Cross-sectional } \\
\text { study }\end{array}$ & 921 & $\begin{array}{l}\text { As the pregnancy progresses, reference ranges of } \mathrm{PI} \text { and } \mathrm{RI} \text { decreased } \\
\text { significantly (PI: } 0.89-0.65 ; \mathrm{RI}: 0.45-0.35) \text {. }\end{array}$ \\
\hline $\begin{array}{l}\text { Guedes-Martins et al. } \\
2014 \text { (19) }\end{array}$ & Portuguese & $6-10$ & $\begin{array}{l}\text { Cross-sectional } \\
\text { study }\end{array}$ & 312 & $\begin{array}{l}\text { PI 90th: } 4.040 \text { ( } 6 \text { weeks), } 3.374 \text { (7 weeks), } 3.150 \text { (8 weeks), } 2.486 \text { (9 weeks), } \\
2.307 \text { (10 weeks); RI 90th: } 1.000 \text { ( } 6 \text { weeks), } 0.977 \text { (7 weeks), } 0.914 \text { (8 weeks), } \\
0.864 \text { (9 weeks), } 0.803 \text { (10 weeks). }\end{array}$ \\
\hline $\begin{array}{l}\text { Ridding G et al. } 2014 \\
\text { (20) }\end{array}$ & Australian & $11-13+6$ & Prospective study & 298 & Gestational age and the mean PI was negatively correlated. \\
\hline $\begin{array}{l}\text { Stridsklev et al. } 2017 \\
(21)\end{array}$ & Norwegian & $8-24$ & Longitudinal study & 124 & The 97.5th percentile of PI varied from 1.03 to 4.07 . \\
\hline
\end{tabular}

$R I$, resistance index; $C l$, confidence interval; PI, pulsatility index; $S / D$, systolic/diastolic velocity. 
Clinically, transabdominal ultrasonography is more acceptable, primarily because it is non-invasive with excellent repeatability. A prospective study compared the UtA-PI values using transabdominal or transvaginal ultrasound at 11-13 + 6 weeks of gestation (27). The results revealed that transabdominal ultrasound showed lower UtA-PI values $(P<0.05)(27)$.

\section{UAD IN RECURRENT PREGNANCY LOSS (RPL)}

RPL refers to two or more pregnancy losses before 20-24 weeks of pregnancy (28). It is a critical reproductive disease, with an incidence rate of $5 \%$ in couples of childbearing age (29). The causes of RPL include uterine malformations, chromosomal abnormalities, immune abnormalities, endocrine or metabolic diseases, thrombophilia, and genetic factors $(30,31)$. The etiology of $50 \%$ of RPL patients is unclear (32). There is evidence that the occurrence of RPL may be related to the decrease of blood perfusion in the endometrium and myometrium (8, 33-35).

Patients with unexplained RPL (uRPL) had increased uterine artery resistance and decreased sub-endometrial blood flow (36). $\mathrm{UAD}$ is an indicator of the state of uterine blood circulation in URPL patients (8). One study tested 214 pregnant women for uterine artery blood flow by transvaginal color Doppler ultrasound at 5-12 weeks of pregnancy (37). The study formed two groups based on whether these women could continue their pregnancies at 20 weeks (37). The results showed that the S/D ratio of uterine artery in pregnant women who could continue the pregnancies was significantly lower than that of the abortion group ( 4.3 vs. $5.3 ; P=0.0001$ ) (37). It suggests that the change of blood flow in the uterine vascular bed could help predict embryo loss in early pregnancy (37). Several studies have confirmed that the mid-cycle uterine artery blood flow was markedly reduced in RPL females $(33,38)$. However, studies also reported that no significant difference was present in PI, RI or S/D ratio of the uterine artery between RPL patients and healthy pregnant women at 18-23 days of the menstrual cycle (10). Therefore, a randomized controlled study with large samples is required for further analysis.

Antinuclear antibodies (ANA) is a crowd of autoantibodies against nuclear and cytoplasmic antigens. There is a higher likelihood for ANA to occur in RPL patients compared with normal pregnant women (39). ANA positive patients had a higher probability of poor outcomes among women with in vitro fertilization (IVF), indicating the harmful effect of ANA on the development of oocytes and embryos (40). One study measured UtA-PI in 26 uRPL patients and 26 normal women during the follicular and mid-luteal phase, respectively (41). In both test periods, UtA-PI of ANA positive RPL patients was significantly higher than that of ANA negative RPL patients and healthy women (41). ANA is likely to change the hemodynamics of the uterine artery by affecting the intensity and impedance of uterine artery, resulting in URPL (41). A previous study also confirmed these findings (8). However, ANA results did not have a relationship with UtA-PI in normal pregnancies (8). Besides,
UtA-PI of ANA positive uRPL patients was also higher than that of healthy pregnant women in early pregnancy (42).

Over the recent years, researchers have begun to pay attention to the uterine radial artery (URA), which is the lower branch of the uterine artery passing through the endometrium. As a result, URA can better reflect the blood flow of the endometrium (43). Compared with UtA, URA can better represent the blood flow transmitted to the fetus in the first trimester (44). After 5 weeks of gestation, URA-RI decreases significantly, which may represent the recasting of blood vessels at the maternal-fetal interface during placentation (44). Meanwhile, after 10 gestational weeks, there is a marked reduction of UtA-RI, reflecting the total uterine blood flow related to the uterine enlargement (44). A prospective study examined the blood flow of URA in 33 RPL patients and 47 normal pregnant women at 5-7 weeks of gestation (45). It was found that URA-RI of RPL patients was significantly higher than that of normal controls $(P<0.05)(45)$. In addition, the proportion of peripheral blood natural killer (pbNK) cells in RPL patients was positively correlated with URA-RI $(P<0.05)$ (45). Another retrospective analysis involved 139 patients with RPL and thrombophilia (5). URA-RI at 8 gestational weeks was notably higher in patients who had an abortion in the index pregnancy than that of pregnant women who delivered live newborns (5). After covariates such as maternal age, BMI, and the number of abortions were adjusted, the risk of abortion was raised by $18.7 \%$ when URA-RI increased by 0.1 at 8 weeks of pregnancy (5). These studies emphasized the importance of detecting the blood flow of UtA and URA in RPL patients.

\section{UAD AND PE/FGR}

$\mathrm{PE}$ is a leading cause of maternal and perinatal death in both developed and under-developed countries. It is the cause of nearly $10-15 \%$ of maternal deaths (46). Pregnant women with $\mathrm{PE}$ face an elevated risk of cardiovascular disease in the future (47). FGR is often associated with PE, which means that the predicted fetal weight is below the 10th percentile due to poor placental formation, or even if the ultrasound is normal, the predicted fetal weight is below the third percentile $(48,49)$. FGR is the primary cause of perinatal morbidity and mortality. At present, it is challenging to distinguish FGR caused by decreased placentation from healthy small infants.

In the past decades, numerous studies have revealed reliable and safe indicators to predict PE. PE or FGR is more likely to occur in pregnant women with alternations in pregnancyassociated plasma protein-A (PAPP-A), placental growth factor (PlGF), and soluble fms-like tyrosine kinase-1 (sFlt-1) levels (50, 51). However, it is challenging to carry out these expensive tests in economically under-developed areas. Moreover, countries that spend less on health care may not increase additional investment in research to change current guidelines. Underdeveloped countries should seek advanced means to adjust the current strategy, benefiting more people (52). UAD is such an economical approach, which may provide a novel method to forecast PE and FGR in under-developed countries. 


\section{Studies of UAD in the First Trimester}

Recently, researchers have increasingly studied the application of $\mathrm{UAD}$ in the first trimester (Table 2). A study considered uterine artery mean PI $>2.35$ as the cut-off value for predicting PE or FGR among low-risk pregnant women at 11-14 weeks of gestation (55). The predictive sensitivity of UtA-PI greater than the 95th percentile was low (12-27\%); however, the specificity was very high (95\%) (55). According to this article (55), UAD at 11-14 weeks can confirm most pregnant women who will have PE and/or FGR. A prospective research involved 120 Caucasian pregnant women with high-risk factors for PE at 1114 gestational weeks (70). Accordingly, the predictive sensitivity of UtA-PI for PE was 61.5, and the specificity was $63.8 \%(70)$. Adding the bilateral notch improved the sensitivity (65.4\%) and specificity (66\%) (70). Therefore, the authors believed that UAD was a useful non-invasive method for predicting PE, especially in areas with poor economic conditions and unable to afford other detection items (70). However, in a separate study, UtAPI greater than the 95th percentile had only $23.9 \%$ sensitivity for predicting PE among 999 low-risk pregnant women in early pregnancy (58). In the first trimester, the application of $\mathrm{UAD}$ alone for predicting gestational hypertension is limited, and other indices should be considered to combine with UAD (58). A prospective study examined the uterine artery blood flow in 405 pregnant women at 11-13 +6 weeks (68). The experiment did not find any significant difference in UtA-PI and the presence of uterine artery notch between pregnant women with PE and those without PE (68). Besides, a large sample study of 8,061 pregnant women revealed that the lowest UtAPI of pregnant women with PE was significantly higher than that with normal pregnancy outcomes (71). Meanwhile, some experts highlighted that a single value of UtA-PI can not precisely reflect the uterine artery resistance, so they recommended using the mean PI in multiples of the median (MoM) after adjusting the basic maternal data (72). Another study measured the uterine artery blood flow in 3,058 pregnant women at 1114 weeks (60). Follow-ups confirmed that 57 of them had full-term PE and 33 experienced preterm PE (60). UtA-RI of preterm PE patients (mean RI: 0.79) was significantly higher than that of patients with normal pregnancy outcomes (mean RI: 0.70) or full-term PE (mean RI: 0.72; $P<0.05$ ) (60). However, there was no significant difference in UtA-RI and the appearance of bilateral notch between full-term PE and normal pregnant women (60).

A meta-analysis explored the predictive effect of UAD on PE and FGR in early pregnancy (3). The authors assessed 55,974 females in 18 studies, and 15 of them were performed among low-risk pregnant females (3). In early pregnancy, the predictive sensitivity of anomalous UAD on PE and earlyonset PE was 26.4 and $47.8 \%$, respectively (3). Moreover, $15.4 \%$ of FGR could be forecasted, and the prediction sensitivity of early-onset FGR was 39.2\% (3). Similarly, another metaanalysis of 298,329 primiparas from 76 studies suggested that the prediction of UAD on adverse pregnancy outcomes was limited in the first and early stage of the second trimester of pregnancy (73). As an independent index, UAD has a medium predictive effect in the low-risk population in the first trimester, around $40-70 \%$ (1). The prediction ability for earlyonset $\mathrm{PE}$ can reach more than $90 \%$ using the multi-parameter prediction model, including UtA-PI, maternal characteristics, and biochemical indices (1).

\section{Studies of UAD in the Second Trimester}

It could be beneficial to screen UAD in a high-risk population in the second trimester. Reportedly, at 23-24 weeks, the detection rate of abnormal uterine artery blood flow to PE was $45 \%$ in high-risk pregnant women (2). After 20 gestational weeks, UtARI greater than the 90th percentile is a potential indicator of gestational hypertension or FGR for pregnant women with a moderate risk of PE (74). For high-risk multiparous pregnant females, most pregnant women who have a bilateral notch with $\mathrm{RI} \geq 0.55$ and a unilateral notch with $\mathrm{RI} \geq 0.65$ at 20 weeks will experience adverse pregnancy outcomes due to poor placentation (75). Compared with clinical high-risk factors, UAD has a better predictive effect on PE and SGA neonates among high-risk females at 22-24 weeks (76).

Uterine artery monitoring among low-risk pregnant women is also helpful in the second trimester $(59,77,78)$. A UtA-PI greater than 1.45 in the second trimester was a critical indicator in predicting PE in low-risk pregnant women (66). The detection of uterine artery Doppler waveform and the appearance of a notch in the second trimester can be used to monitor pregnant women who may have adverse pregnancy outcomes (66). A retrospective study analyzed the uterine artery blood flow in 1,472 pregnant women from 19 to 22 gestational weeks (79). Pregnant women with high UtA-RI, PI or the appearance of a diastolic notch were more likely to develop FGR, SGA, lower Apgar score at birth, increased cesarean section rate, spontaneous preterm birth (PTB), and placental abruption $(P<0.05)$ (79). The appearance of diastolic notch markedly promoted the incidence of severe PE, HELLP syndrome and oligohydramnios (79). It has been reported that the appearance of uterine artery notch show impaired endothelial function $(80,81)$. The uterine artery testing of 30,639 unselected pregnant women revealed that UAD at 2224 weeks could predict most early-onset $\mathrm{PE}$ rather than late-onset PE (4).

It is also necessary to detect the presence of uterine artery notch in the second trimester. The detection of UAD in 652 pregnant women at 12-16 weeks of pregnancy revealed that the existence of bilateral notches elevated the incidence of PE, spontaneous PTB, and SGA newborns (78). Another study that included 1,536 pregnant women at 16-23 gestational weeks revealed that the positive likelihood ratios of mean notch depth index (mNDI) and mean pulsatility index (mPI) for forecasting early-onset PE had a medium predictive effect (82). It suggests that $\mathrm{mNDI}$ or $\mathrm{mPI}$ in the second trimester can help identify highrisk groups that might have early-onset PE (82). Besides, other studies have shown that the combination of NDI and UtA-PI can predict different adverse pregnancy outcomes, such as placental abruption, FGR, stillbirth, and spontaneous PTB before 32 weeks $(83,84)$.

A few studies with large sample numbers have obtained valuable results. A multicenter analysis detected UtA-PI in 7,851 pregnant women at 23 gestational weeks (54). The sensitivity 
TABLE 2 | Studies on uterine artery Doppler (UAD) in preeclampsia (PE) and fetal growth restriction (FGR).

\begin{tabular}{|c|c|c|c|c|c|c|}
\hline Authors & Population & $\begin{array}{c}\text { Gestational } \\
\text { weeks }\end{array}$ & $\begin{array}{l}\text { Research } \\
\text { type }\end{array}$ & $\begin{array}{c}\text { Number of } \\
\text { subjects }\end{array}$ & Results & Conclusions \\
\hline $\begin{array}{l}\text { Kurdi W et al. } \\
1998 \text { (53) }\end{array}$ & British & $19-21$ & $\begin{array}{l}\text { Prospective } \\
\text { study }\end{array}$ & 946 & $\begin{array}{l}\text { The OR of women with diastolic notches to } \\
\text { have PE was } 12.8 \text {, and the OR of developing } \\
\text { PE requiring termination of pregnancy before } \\
37 \text { weeks was } 52.6 \text {. }\end{array}$ & $\begin{array}{l}\text { Patients with increased uterine artery } \\
\text { resistance had a higher tendency to } \\
\text { experience pregnancy complications, } \\
\text { particularly the ones needed to terminate } \\
\text { the pregnancy before } 37 \text { weeks. }\end{array}$ \\
\hline $\begin{array}{l}\text { Papageorghiou AT } \\
\text { et al. } 2001 \text { (54) }\end{array}$ & British & $22-24$ & $\begin{array}{l}\text { Prospective } \\
\text { study }\end{array}$ & 7,851 & $\begin{array}{l}\text { The sensitivity of PI greater than the 95th } \\
\text { percentile to predict PE with FGR, PE without } \\
\text { FGR, FGR without PE, PE with or without } \\
\text { FGR, FGR with or without PE were } 69,24 \text {, }\end{array}$ & $\begin{array}{l}\text { Uterine artery Doppler at } 23 \text { gestational } \\
\text { weeks could detect most severe PE } \\
\text { and/or FGR patients. }\end{array}$ \\
\hline
\end{tabular}

$\begin{array}{llll}\text { Martin AM et al. } & \text { British } & 11-14 & \begin{array}{l}\text { Prospective } \\ \text { study }\end{array}\end{array}$

13,41 , and $16 \%$, respectively.

The sensitivity of PI greater than 2.35 to predict PE (with or without FGR) and FGR (without PE) was 27 and $11.7 \%$, respectively. The sensitivities of PE and FGR that requires terminating the pregnancy 32 weeks ago was 60.0 and $27.8 \%$, respectively.

$\begin{array}{lllll}\begin{array}{l}\text { Phupong V et al. } \\ 2003 \text { (56) }\end{array} & \text { Thai people 22-28 } & \begin{array}{l}\text { Prospective } \\ \text { study }\end{array} & 322 \\ & & & \\ \begin{array}{l}\text { Vainio M et al. } \\ 2005 \text { (57) }\end{array} & \text { Finnish } & 12-14 & \begin{array}{l}\text { Prospective } \\ \text { trial }\end{array} & 120 \\ & & & \\ \begin{array}{l}\text { Gómez O et al. } \\ 2005 \text { (58) }\end{array} & \text { Spanish } & 11-14 & \begin{array}{l}\text { Prospective } \\ \text { study }\end{array} & 999\end{array}$

2005 (58) study

The sensitivity, specificity, PPV, and NPV to respectively; and those for SGA neonates were $67,82.9,6.9$, and $99.2 \%$, respectively.

As the pregnancy progresses, the sensitivity, specificity, PPV and NPV of bilateral notches to predict gestational hypertension ranged from 91-35, 41-94, 7-70, and 86-97\%. In comparison with healthy pregnancies, pregnant women with complications had higher $\mathrm{PI}$ and an elevated incidence of bilateral notch $(P<0.05)$.

Ricardo $S$ et al. Brazilian 2008 (59)

$22-24$

Prospective study

1,057

The RRs of $\mathrm{PI}>1.55$ for PE and FGR were 7.3 and 3.9.

11-14 Prospective 3,058
2008 (60)

Plasencia W et al. British 2008 (61)

Melchiorre K et al. British 2009 (62)

\author{
Ghi T et al. $2010 \quad$ Italian \\ (63)
}
20-22; 26-28 Prospective study

$11-13+6$ Prospective and $21-24+6$ study

3,107

UtA-RI of preterm PE patients was significantly higher than that of healthy pregnant females or full-term PE women $(P<$ 0.05). There was no significant difference in UtA-RI and the presence of diastolic notch between full-term PE patients and normal pregnancies.

UAD betwen 11 and 14 weeks confirms most patients with severe PE and/or FGR.

(n)

It is likely that pregnant women with diastolic notch would have PE and SGA neonates.

The detection of diastolic notches between 12 and 14 weeks could be an indicator of gestational hypertension in high-risk pregnant females.

UtA-PI in gestational hypertension patients increased significantly during early pregnancy. Nevertheless, the clinical significance of only monitoring the uterine artery was relatively small in the low-risk population in the first trimester.

UAD at 22-24 weeks can be used to identify pregnant women with complications due to poor placental function.

Indeed, UAD in early pregnancy was related to preterm PE. However, this study did not support adding UAD to routine prenatal examination.

Maternal characteristics, UtA-PI at 11-13 + 6 Useful monitoring for PE could be realized weeks, and the change of UtA-PI from 11-13 by the Doppler detection of UtA-PI at 11 +6 weeks to $21-24+6$ weeks were to $13+6$ weeks and the alternation in PI remarkable independent indicators to predict between 11 and $13+6$ and 21 to $24+6$ PE. weeks.

Compared with normal pregnancies, UtA-RI There was a significant correlation and the presence of diastolic notch in the first between UtA-RI in early pregnancy and trimester among pregnant women with SGA the following SGA neonates. newborns were significantly higher.

Compared with pregnant women with nominal uterine artery blood flow at 22-22 weeks and those with normal uterine artery parameters at 26-28 weeks, patients with persistent abnormal UAD were more prone to PE, SGA neonates and admission to NICU.

$\begin{array}{llll}\text { Maroni E et al. } & \text { Italians } & 34 & \begin{array}{l}\text { Prospective } \\ \text { study }\end{array}\end{array}$

For low-risk primiparas with abnormal UAD in the second trimester, the probability of pregnancy complications increased if UAD at 26-28 weeks was persistently abnormal.

Elevated UtA-PI at 34 weeks was an independent indicator of a higher incidence of having an SGA infant.
Pregnant women with elevated UtA-PI exhibited an earlier gestational week of delivery, having lighter fetal weight and a higher proportion of SGA fetus $(P<0.05)$. 
TABLE 2 | Continued

\begin{tabular}{|c|c|c|c|c|c|c|}
\hline Authors & Population & $\begin{array}{l}\text { Gestational } \\
\text { weeks }\end{array}$ & $\begin{array}{l}\text { Research } \\
\text { type }\end{array}$ & $\begin{array}{l}\text { Number of } \\
\text { subjects }\end{array}$ & Results & Conclusions \\
\hline $\begin{array}{l}\text { Lai J et al. } 2013 \\
\text { (65) }\end{array}$ & British & 30-33 & $\begin{array}{l}\text { Prospective } \\
\text { study }\end{array}$ & 4,294 & $\begin{array}{l}\text { By combining maternal factors and UtA-PI, } \\
70.3 \% \text { intermediate- ( } 34-37 \text { weeks) PE and } \\
54.6 \% \text { late-PE ( }>38 \text { weeks) could be found. }\end{array}$ & $\begin{array}{l}\text { Combination of maternal factors and } \\
\text { UtA-PI at 30-33 weeks could } \\
\text { authentically recognize females with a } \\
\text { higher probability of PE. }\end{array}$ \\
\hline $\begin{array}{l}\text { Barati M et al. } \\
2014(66)\end{array}$ & Iranian & $16-22$ & $\begin{array}{l}\text { Cross- } \\
\text { sectional } \\
\text { study }\end{array}$ & 379 & $\begin{array}{l}\text { The sensitivity, specificity, NPV, PPV of UtA-PI } \\
\text { greater than } 1.45 \text { for predicting PE were } \\
95 . \%, 79,98.9 \text {, and } 88.2 \% \text {, respectively. For } \\
\text { predicting SGA, the corresponding numbers } \\
\text { were } 96.5,57,99.2 \text {, and } 23.5 \% \text {, respectively. }\end{array}$ & $\begin{array}{l}\text { UAD detection at } 16-22 \text { weeks could be } \\
\text { a suitable instrument to predict PE and } \\
\text { SGA. }\end{array}$ \\
\hline $\begin{array}{l}\text { Parry S et al. } 2017 \\
\text { (67) }\end{array}$ & American & $16-22+6$ & $\begin{array}{l}\text { Prospective } \\
\text { study }\end{array}$ & 8,024 & $\begin{array}{l}\text { The nominal thresholds of uterine artery } \\
\text { indices were related to SGA. However, they } \\
\text { had low PPVs (<15\%) and unsatisfactory } \\
\text { AUCs }(0.5-0.6) \text {. }\end{array}$ & $\begin{array}{l}\text { UAD measurement in the early second } \\
\text { trimester was not an effective means to } \\
\text { predict SGA infants. }\end{array}$ \\
\hline $\begin{array}{l}\text { Prakansamut N } \\
\text { et al. } 2019(68)\end{array}$ & Thai people & $11-13+6$ & $\begin{array}{l}\text { Prospective } \\
\text { study }\end{array}$ & 405 & $\begin{array}{l}\text { A significant difference was not present in } \\
\text { UtA-PI and the presence of uterine artery } \\
\text { notch between PE patients and those } \\
\text { without PE. }\end{array}$ & $\begin{array}{l}\text { UtA-PI in the first trimester is not an } \\
\text { independent predictor for PE. }\end{array}$ \\
\hline $\begin{array}{l}\text { Običan SG et al. } \\
2020 \text { (69) }\end{array}$ & American & 24-36 & $\begin{array}{l}\text { Nested } \\
\text { case control } \\
\text { study }\end{array}$ & 200 & $\begin{array}{l}\text { Patients with diastolic notch in the left uterine } \\
\text { artery and PI greater than the 95th percentile } \\
\text { faced an elevated risk of pregnancy } \\
\text { complications. }\end{array}$ & $\begin{array}{l}\text { UAD had a moderate predictive effect } \\
\text { when predicting adverse maternal and } \\
\text { fetal outcomes. }\end{array}$ \\
\hline
\end{tabular}

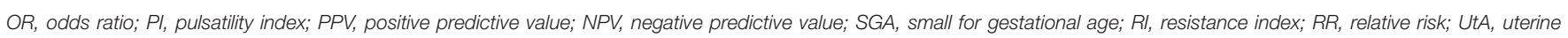
artery; NICU, neonatal intensive care unit; AUC, areas under receiver operating characteristic curves.

of UtA-PI greater than the 95th percentile for predicting PE (with or without FGR) and FGR (with or without PE) was 41 and $16 \%$, respectively (54). Moreover, for pregnant women who terminated their pregnancies before 32 weeks due to PE with FGR, PE without FGR, or FGR without PE, the sensitivity of UtA-PI was 93, 80, and 56\%, respectively (54). In a retrospective study including 23,894 pregnancies at 19-24 gestational weeks, UtA-PI alone identified 25-77\% SGA (less than the 5th quantile) who had deliveries at different gestational weeks with a false positive rate (FPR) of $10 \%$ (85). In a meta-analysis with 79,547 PE patients and 41,131 FGR pregnancies, the positive likelihood ratio of increased UtA-PI and the presence of notch to predict PE was the highest (21 in a high-risk population and 7.5 in a low-risk population) (86).

However, the outcomes of a study performed in low-risk primiparas suggested that UAD in the second trimester had a slight predictive effect on PE (9). Similarly, another analysis examined the uterine artery blood flow in 2,489 low-risk pregnant women at 22 weeks (87). The results of the logistic regression model showed that the predictive sensitivity of PE and SGA were only $44.8 \%$ and $28.1 \%$, respectively (87). Accordingly, UAD was not beneficial to predict PE and FGR in the lowrisk population at 22 weeks (87). Moreover, scholars collected 8,024 primiparas and tested their uterine artery blood flow from 16 to $22+6$ weeks (67). The typical thresholds of uterine artery parameters were related to SGA (67). However, all positive predictive values (PPV) were less than $15 \%$, and the areas under receiver operating characteristic curves (AUCs) was $0.5-0.6$ (67). The study indicated that UAD in the early second trimester executed weak functionality on predicting SGA neonates (67). The contradiction in the findings may be related to the heterogeneity of research objects, different gestational weeks, and the diverse reference range of uterine artery parameters.

\section{Studies of UAD in the Third Trimester}

Some studies have reported that the continually increasing resistance of blood flow in the uterine artery in PE, FGR, or SGA patients during the third trimester may lead to many adverse pregnancy outcomes (88-96). These adversities include stillbirth, cesarean section due to fetal distress, and decreased $\mathrm{PH}$ of the umbilical cord (88-96). A comparative analysis of the pregnancy outcomes between normotensive patients with increased UtAPI and pregnant women with normal uterine artery blood flow at 34 weeks of gestation revealed that pregnant women with increased UtA-PI delivered at earlier gestational weeks, having lower fetal weight, and a higher incidence of SGA infants $(P$ $<0.05$ ) (64). Admittedly, the predictive effect of UtA-PI on late-onset PE was lower than that of early-onset PE. However, recent findings suggest that the predictive effectiveness of lateonset PE by UtA-PI gradually increases in the third trimester $(97,98)$. In addition, another study found that UtA-PI of fullterm PE patients increased significantly only from 33 weeks, indicating the necessity to monitor uterine artery blood flow in the third trimester (99). The increase of UtA-PI in fullterm $\mathrm{PE}$ patients in the third trimester may be the result of vasoconstriction in uterine placental circulation just before the onset of the disease, instead of the defective placentation at early pregnancy. A research analyzed UAD in 86 late-onset PE patients (>34 weeks) (100). It was found that the abnormalities of UAD were associated with severe PE, late spontaneous PTB, SGA, 
and neonatal intensive care unit (NICU) admission $(P<0.05)$ (100). Accordingly, UAD was associated with placental apoptosis, indicating that placental dysplasia caused some late-onset PE cases (100).

Remarkably, regarding screening patients with late-onset placental-related diseases, the detection of UtA-PI in the third trimester performed better than that in the first trimester, since they had new-onset increased UtA-PI in the third trimester instead of the first trimester (101). The plausible reason is that increased UtA-PI in the third trimester is not related to the change of trophoblasts. Further, there was no significant change in the uterine artery blood flow between patients with abnormal placental implantation and pregnant women with normal placental implantation $(102,103)$. In addition, the changes of the uterine artery in the third trimester could also be related to cardiac output, physiological changes of the blood system, and systemic vascular resistance (104). There is a hypothesis that increased UtA-PI in the third trimester may cause subsequent $\mathrm{PE}$, which is related to the change of the maternal blood system. Besides, the report that $\mathrm{PE}$ is related to cardiac recasting and significant cardiac damage supports the theory (105). Reportedly, the maternal cardiovascular function determines whether a pregnant woman will have PE (106). Indeed, there is evidence that late-onset increased UtA-PI is associated with abnormal maternal hemodynamics (106). However, a study found that placental hypo-perfusion occurred in $66.7 \%$ of placentas in patients with late-onset SGA neonates (107). The abnormal development of distal villous caused nearly 25 of placental hypo-perfusion, and 50\% was due to the blockage of blood vessels, resulting in elevated UtA-PI during the third trimester (108).

\section{Sequential UAD Screening}

A study performed sequential detection of UAD in 870 pregnant women at 11-14 and 19-22 weeks, respectively (109). Based on the outcomes, pregnant women with persistently elevated UtAPI faced the greatest risk for gestational hypertension and FGR (109). The changes in the uterine artery blood flow from the first trimester to the second trimester were related to gestational hypertension and FGR (109). A separate sequential analysis detected UtA-PI in 3,107 pregnant women at 11-13 + 6 weeks and 21-24 + 6 weeks (61). Multiple regression analysis showed that maternal factors, UtA-PI at 11-13 + 6 weeks, and the alternation of UtA-PI from 11-13 + 6 weeks to 21-24 + 6 weeks were independent factors to predict PE (61). Compared with PE patients, UtA-PI was significantly less in normal pregnant women from $11-13+6$ weeks to $21-24+6$ weeks (61). The continuous monitoring could re-evaluate $75 \%$ of patients who were assessed as the high-risk population in 11-13 +6 weeks as low-risk patients at 21-24 + 6 weeks to avoid the anxiety of these pregnant women and reduce the workload of physicians (61). Moreover, practitioners chose 243 unselected pregnant women to test for uterine artery notches at 12-14 and 22-24 gestational weeks (110). They found that patients without a notch or early disappearance of notches rarely had adverse pregnancy outcomes due to poor placentation (110). A retrospectively study reviewed the results of UtA-PI in 5,887 pregnant women in the second and third trimesters (111). Patients with continuously increased UtA-PI were more likely to develop gestational hypertension compared to those without $(P<0.05)(111)$. The results indicate an association between the continuous deterioration of uterine artery blood flow and gestational hypertension, independent of UtA-PI recorded in the second trimester (111).

\section{The Combination of UAD and Other Factors}

UtA-PI can be combined with maternal factors, biophysical and biochemical indicators at 11-13 + 6 weeks to predict PE and SGA (112). Combining maternal factors, UtA-PI, mean arterial pressure (MAP), and PlGF can forecast 75 of preterm PE and 47\% of full-term PE (113). Between 19 and 24 gestational weeks, combination of maternal factors, PI, and PlGF could predict 99,85 , and $46 \%$ of PE before 32 weeks, before 37 weeks, and after 37 weeks, respectively (114). The combination of UtA-PI and biochemical indices in the second trimester exhibited higher sensitivity than the prediction by medical history alone (114). At 30-34 weeks of gestation, combined detection with maternal factors, UtAPI, MAP, PlGF, and sFlt-1 identified 99 of preterm PE and $49 \%$ of full-term PE (97). Accordingly, UtA-PI combined with maternal factors and biochemical indicators in the third trimester could find almost all preterm PE and half full-term PE with 5\% of FPR (97). However, an empirical analysis from two British hospitals showed that UtA-PI at 30-34 weeks of gestation could predict 79 premature PE and $42 \%$ full-term PE (115). Moreover, combining biochemical results and MAP in early and/or middle pregnancy with UtA-PI did not have a significant improvement in predicting preterm PE and full-term PE (115).

According to some studies, the combination of maternal variables, abnormal UAD, and low PAPP-A levels in the first trimester may help predict PE and SGA in the third trimester $(116,117)$. Combining serum Split and Hairy-related Protein 1 (SHARP1), inhibin-A expressions, sFlt-1/PlGF ratio, and UAD could also enhance the screening efficacy for predicting PE (68, $118,119)$. A recent prospective research studied 378 pregnant women with high-risk factors for early-onset PE by adopting the multivariate prediction model of early pregnancy (120). The sensitivity of predicting SGA by combining UtA-PI, PlGF, and sFlt-1 was low in the third trimester (120). However, a high negative predictive value can alleviate the anxiety of pregnant women, avoid unnecessary medical intervention, and formulate individualized treatment plans for high-risk groups (120). The contradicting results of different studies may be due to the diverse definitions of $\mathrm{PE}$ and FGR, different methods of Doppler detection (pulsed, color or continuous wave), distinct diagnostic criteria of positive cases, different subjects, and the usage of aspirin and/or low molecular weight heparin (LMWH). 


\section{UAD AND STILLBIRTH}

Poor placentation could likely be the etiology of stillbirth. Reasonable prenatal intervention and timely treatment may lessen the incidence of stillbirth (121). In the first trimester, $61 \%$ of stillbirths due to poor placentation could be identified by combining maternal factors, UtA-PI, fetal ductus venosus PI for veins, and PlGF, with a FPR of $10 \%$ (122). In contrast, the sensitivity of UAD alone in predicting stillbirth in the first trimester was only $14.5 \%$ (3). A study included 15,835 pregnant women in the second trimester, and 144 experienced stillbirths (123). Pregnant women with uterine artery parameters greater than the 90th percentile had a 7 -fold higher risk of stillbirth than those with uterine artery parameters below the 90th percentile (123). Besides, another prospective study with a large sample size including 70,003 pregnant women also showed that a combination of maternal factors, UtA-PI and fetal measurement parameters in the second trimester could predict 55 of stillbirths, of which $75 \%$ were caused by defective placentation (124). Reportedly, UAD in the second trimester effectively predicts early stillbirths caused by PE, placental abruption, or SGA, instead of late stillbirth without PE, placental abruption, or SGA (125). Additionally, a study of 30,519 pregnant women showed that higher UtA-PI in the second trimester had a high predictive sensitivity for stillbirth occurred before 32 weeks caused by placental issues (126). UtA-PI combined with cerebroplacental ratio (CPR) and estimated fetal weight (EFW) could predict stillbirth in the third trimester with a sensitivity of $66.7 \%$, specificity of $92.1 \%$ (95).

\section{UAD AND SPONTANEOUS PTB}

Spontaneous PTB refers to delivery before 37 weeks of pregnancy with a worldwide incidence of around 11\% (127). Reportedly, abnormal placental formation and decreased uterine artery blood flow were related to spontaneous PTB $(128,129)$. UtAPI in the first trimester could not predict spontaneous PTB effectively (130). Regarding the relationship between UtA-PI and spontaneous PTB in the second trimester, UtA-PI was higher in patients with deliveries before 33 weeks when compared with those who had childbirth at and after 33 weeks (131). The increase of UtA-PI in patients with spontaneous PTB may be the result of decreased placental function, since histopathological findings have revealed that the remodeling of uterine spiral arteries in these patients was insufficient (128). However, this study showed that UAD did not predict better than maternal medical history and clinical features (131). Another study tested 4,521 pregnant women for UAD at 18-22 weeks of pregnancy (132). UtA-RI of spontaneous PTB patients was significantly higher than that in full-term pregnant women $(1.12$ vs. $1.04 ; P<0.05)$. Patients with increased UtA-RI had an elevated risk of spontaneous PTB (OR 2.9 per unit; 95\% CI 2.4-3.9) (132). Nearly one-third of pregnant women with bilateral diastolic notches had spontaneous PTB (132). The analysis pointed out that UtA-RI in the second trimester was a weak predictive index of spontaneous PTB (132). A retrospective study compared UtA-RI measured during the second trimester between 234 spontaneous PTB patients and 5,472 full-term pregnant females (133). There was no significant difference in UtA-RI between the two groups (133).

\section{UAD AND TWIN PREGNANCY}

In the first $(134,135)$ and second trimesters $(136)$, the UtA-PI of twin pregnant women was significantly lower than that of a single pregnant female. Similarly, in the second trimester, the UtA-RI of twins was markedly lower than that of singletons (137). The overall reduced UtA-PI and RI may represent an increased placental implantation area and distinct changes in maternal hemodynamics in twin pregnancy. Another study confirmed that the UtA-PI of twin pregnancies was lower than that of a single pregnancy from 17 to 38 weeks of gestation (138). According to this study, it is necessary to establish the normal range of uterine artery parameters for twin pregnant women to distinguish between high-risk pregnant women and low-risk population (138). It has also been reported that the UtA-PI of dichorionic twins was lower than that of monochorionic twins in the first (134) and the second trimesters (139). However, other studies have not confirmed the result. In fact, some studies reported that there were no differences in the UtA-PI between monochorionic and dichorionic pregnancies in the first trimester (135) and the second trimesters (140). This shows that the total size of placenta determines the blood flow of uterine artery, rather than the genetic or hormonal factors related to chorionicity (141).

Higher UtA-PI in early pregnancy was related to PE and SGA in the index pregnancy, suggesting that UAD in the first trimester could predict adverse pregnancy outcomes in twin pregnancy (135). The predictive validity of UtA-RI for forecasting gestational hypertension and/or PE was frustratingly low in twin pregnancies from 20 to 24 weeks (137). In another study performed in second trimester, the sensitivity of mean, lowest and highest UtA-PI for predicting PE was 35, 29, and $27 \%$, respectively (136). Still, the sensitivity was not very high. However, the authors believed that the screening of uterine arteries had great clinical significance considering the increased probability of PE in twins (136). In a study that included 406 healthy twin pregnant women in the second trimester, the authors found that the sensitivity of UAD for predicting adverse complications was lower than that of singletons (139). Likewise, a retrospective study comprising 256 dichorionic twin pregnant women has been conducted (142). Accordingly, the sensitivity of UAD in predicting adverse pregnancy outcomes was low despite the application of the reference interval for twins (142). The negative predictive value of UAD in twins was lower than that in singletons, suggesting that adverse pregnancy outcomes could still occur despite the existence of normal uterine artery blood flow in twins (142). It indicates that the etiologies of PE and FGR in twins may have other causes that are not associated with placental dysfunction (142). Besides, there is no consensus on whether low-dose aspirin can prevent PE in high-risk twins before 16 weeks of pregnancy (143). Thus, 
the application of UAD in twin pregnant women seems to be limited.

\section{CLINICAL IMPLICATIONS OF SCREENING UAD}

Predicting pregnancy complications in advance allows practitioners to prevent and carry out timely interventions to avoid or lessen the harm to mothers and neonates. Administering low-dose aspirin daily before 16 weeks of pregnancy can significantly reduce the incidence of pregnancy complications, including spontaneous PTB, FGR, PE, and perinatal death (144). The Cochrane review, published in 2019 (145), found that in pregnant women with a risk of developing $\mathrm{PE}$, the use of low-dose aspirin reduced the risk of PE, spontaneous PTB, and perinatal death by 18,9 , and $14 \%$, respectively. Noticeably, aspirin slightly increases the incidence of postpartum hemorrhage and placental abruption (145). Besides, preventive treatment using aspirin in pregnant women with abnormal uterine artery blood flow in the second trimester can significantly reduce the incidence of PE (146). However, another meta-analysis indicated that commencing aspirin treatment in the second trimester has minimal effect in reducing the risk of subsequent PE (147). A recent report revealed that aspirin could reduce the risk of preterm PE, rather than full-term PE, only when it was prescribed from 16 weeks' gestation at a daily dosage of more than $100 \mathrm{mg}$ (148). Although the preventive effect of aspirin in the second trimester is not clear, the risk stratification of pregnant women in the second and third trimesters can strengthen the monitoring of the high-risk population and formulate an individualized mode and timing of delivery. Additionally, the application of LMWH can improve uterine artery blood flow and help obtain good pregnancy outcomes in uRPL patients with increased URA-RI (45). Reportedly, alternative therapeutic approaches comprising nitric oxide, sildenafil, omega 3, and vitamin E can also increase uterine artery blood flow in pregnancy complications $(36,149-151)$.

Under modern clinical settings, every pregnant woman has a routine ultrasound examination in the first trimester in most parts of the world. In the U.K., additional screening of UAD costs only $18-25$ pounds and an additional 5 min $(152,153)$. The FPR of UAD is relatively low, so it will not increase the anxiety of pregnant women. Besides, the inspection of uterine artery blood flow is a relatively fast and low-cost item. Therefore, it can be regarded as a routine monitoring procedure in obstetrical ultrasound.

\section{REFERENCES}

1. Khong SL, Kane SC, Brennecke SP, da Silva Costa F. First-trimester uterine artery Doppler analysis in the prediction of later pregnancy complications. Dis Markers. (2015) 2015:679730. doi: 10.1155/2015/679730

2. Li N, Ghosh G, Gudmundsson S. Uterine artery Doppler in high-risk pregnancies at 23-24 gestational weeks is of value in predicting adverse outcome of pregnancy and selecting cases for more intense surveillance.

\section{CONCLUSIONS}

According to the published studies, UAD can be used to predict pregnancy complications such as RPL, PE, FGR, stillbirth, and spontaneous PTB. For early-onset PE/FGR caused by poor placentation, the accuracy of prediction was more than $90 \%$ when combining UAD with other biochemical indices. Monitoring UAD among high-risk pregnant women in the third trimester can also help predict late-onset PE/FGR and guide the mode of delivery. A critical aspect of obstetrical work is to seek high-risk groups that may have adverse pregnancy outcomes early. Primiparas have no obstetric history, so it is hard to assess pregnancy risk. Presently, limited medical resources are distributed among all pregnant women, but not among those most likely to have adverse pregnancy results. As a non-invasive examination, UAD can help clinical practitioners identify highrisk groups and implement specific detection and prevention measures. From early pregnancy to late pregnancy, UAD can combine with other maternal factors, biochemical indicators, and fetal measurement data to identify high-risk population. The identification of high-risk population can also lessen maternal mortality. Besides, through moderate risk stratification, stringent monitoring for high-risk pregnant women can be implemented, decreasing the incidence of adversities.

However, inconsistencies in detection methods affect the clinical application of UAD. A unified standard is lacking in terms of a clinically acceptable gestational age at which assessment should be made, the equipment used, and whether to use a diastolic notch or more objective indicators, such as impedance and velocity indices. Besides, the blood circulation in the uterus and placenta is a dynamic process, and the blood flow in a single vessel may change. Therefore, it could be difficult for the parameters of the uterine artery to represent the whole blood circulation state of the maternal-fetal interface in some cases. In the future studies, it is necessary to use standardized detection methods to evaluate the parameter selection and evaluation strategy of UAD in prospective researches with large sample sizes to obtain better prediction approaches. In addition, promoting the understanding of the etiology of pregnancy complications can help find novel detection methods and preventive measures.

\section{AUTHOR CONTRIBUTIONS}

YT and XY drafted the manuscript. XY conceived the idea and revised the manuscript. All authors read, contributed, and approved the final version.
Acta Obstet Gynecol Scand. (2014) 93:1276-81. doi: 10.1111/aogs. 12488

3. Velauthar L, Plana MN, Kalidindi M, Zamora J, Thilaganathan B, Illanes SE, et al. First-trimester uterine artery Doppler and adverse pregnancy outcome: a meta-analysis involving 55,974 Women. Ultrasound Obstet Gynecol. (2014) 43:500-7. doi: 10.1002/uog.13275

4. Yu CK, Khouri O, Onwudiwe N, Spiliopoulos Y, Nicolaides KH. Prediction of pre-eclampsia by uterine artery Doppler imaging: relationship to 
gestational age at delivery and small-for-gestational age. Ultrasound Obstet Gynecol. (2008) 31:310-3. doi: 10.1002/uog.5252

5. Bao SH, Chigirin N, Hoch V, Ahmed H, Frempong ST, Zhang M, et al. Uterine Radial Artery resistance index predicts reproductive outcome in women with recurrent pregnancy losses and thrombophilia. Biomed Res Int. (2019) 2019:8787010. doi: 10.1155/2019/8787010

6. Gudnasson HM, Dubiel M, Gudmundsson S. Preeclampsia-abnormal uterine artery Doppler is related to recurrence of symptoms during the next pregnancy. J Perinat Med. (2004) 32:400-3. doi: 10.1515/jpm.2004.135

7. Acharya G, Wilsgaard T, Berntsen GK, Maltau JM, Kiserud T. Reference ranges for serial measurements of umbilical artery Doppler indices in the second half of pregnancy. Am J Obstet Gynecol. (2005) 192:93744. doi: 10.1016/j.ajog.2004.09.019

8. Habara T, Nakatsuka M, Konishi H, Asagiri K, Noguchi S, Kudo T. Elevated blood flow resistance in uterine arteries of women with unexplained recurrent pregnancy loss. Hum Reprod. (2002) 17:1904. doi: 10.1093/humrep/17.1.190

9. Myatt L, Clifton RG, Roberts JM, Spong CY, Hauth JC, Varner MW, et al. The utility of uterine artery Doppler velocimetry in prediction of preeclampsia in a low-risk population. Obstet Gynecol. (2012) 120:81522. doi: 10.1097/AOG.0b013e31826af7fb

10. Yildiz G, Yavuzcan A, Yildiz P, Göynümer G, Yücel N. Effect of uterine artery blood flow on recurrent pregnancy loss. Clin Exp Obstet Gynecol. (2012) 39:326-9.

11. Sladkevicius P, Valentin L, Maršál K. Blood flow velocity in the uterine and ovarian arteries during menstruation. Ultrasound Obstet Gynecol. (1994) 4:421-7. doi: 10.1046/j.1469-0705.1994.04050421.x

12. Kurmanavicius J, Florio I, Wisser J, Hebisch G, Zimmermann R, Müller $\mathrm{R}$, et al. Reference resistance indices of the umbilical, fetal middle cerebral and uterine arteries at 24-42 weeks of gestation. Ultrasound Obstet Gynecol. (1997) 10:112-20. doi: 10.1046/j.1469-0705.1997.10020112.x

13. Dejthevaporn $T$, Phupong V, Uerpairojkit B, Wacharaprechanont $T$, Tannirandorn Y, Charoenvidhya D. Reference ranges for Doppler indices of uterine arteries in pregnant women during 22-28 weeks' gestation: a study at King Chulalongkorn Memorial Hospital. J Med Assoc Thai. (2002) 85:668-72

14. Mäkikallio K, Tekay A, Jouppila P. Uteroplacental hemodynamics during early human pregnancy: a longitudinal study. Gynecol Obstet Invest. (2004) 58:49-54. doi: $10.1159 / 000077914$

15. Gómez O, Figueras F, Fernández S, Bennasar M, Martínez JM, Puerto $\mathrm{B}$, et al. Reference ranges for uterine artery mean pulsatility index at 11-41 weeks of gestation. Ultrasound Obstet Gynecol. (2008) 32:12832. doi: 10.1002/uog. 5315

16. Liao AW, Toyama J, Costa V, Ramos C, Brizot M, Zugaib M. Correlation between the Doppler velocimetry findings of the uterine arteries during the first and second trimesters of pregnancy. Rev Assoc Med Bras (1992). (2009) 55:197-200. doi: 10.1590/s0104-42302009000200026

17. Flo K, Wilsgaard T, Acharya G, A. new non-invasive method for measuring uterine vascular resistance and its relationship to uterine artery Doppler indices: a longitudinal study. Ultrasound Obstet Gynecol. (2011) 37:53842. doi: 10.1002/uog. 8907

18. Bahlmann F, Fittschen M, Reinhard I, Wellek S, Steiner E. Reference values for blood flow velocity in the uterine artery in normal pregnancies from 18 weeks to 42 weeks of gestation calculated by automatic Doppler waveform analysis. Ultraschall Med. (2012) 33:258-64. doi: 10.1055/s-0031-1281647

19. Guedes-Martins L, Saraiva J, Gaio R, Macedo F, Almeida H. Uterine artery impedance at very early clinical pregnancy. Prenat Diagn. (2014) 34:71925. doi: $10.1002 /$ pd. 4325

20. Ridding G, Schluter PJ, Hyett JA, McLennan AC. Uterine artery pulsatility index assessment at 11-13 weeks' gestation. Fetal Diagn Ther. (2014) 36:299304. doi: $10.1159 / 000361021$

21. Stridsklev S, Salvesen $\varnothing$, Salvesen K, Carlsen SM, Husøy MA, Vanky E. Uterine artery Doppler measurements during first and second trimesters of normal pregnancy. Acta Obstet Gynecol Scand. (2017) 96:36671. doi: 10.1111/aogs.13073

22. Soregaroli M, Valcamonico A, Scalvi L, Danti L, Frusca T. Late normalisation of uterine artery velocimetry in high risk pregnancy. Eur J Obstet Gynecol Reprod Biol. (2001) 95:42-5. doi: 10.1016/s0301-2115(00)00358-4
23. Hofstaetter C, Dubiel M, Gudmundsson S, Marsal K. Uterine artery color Doppler assisted velocimetry and perinatal outcome. Acta Obstet Gynecol Scand. (1996) 75:612-9. doi: 10.3109/00016349609054684

24. Song WL, Zhao YH, Shi SJ, Liu XY, Zheng GY, Morosky C, et al. First trimester Doppler velocimetry of the uterine artery ipsilateral to the placenta improves ability to predict early-onset preeclampsia. Medicine. (2019) 98:e15193. doi: $10.1097 / \mathrm{md} .0000000000015193$

25. Sciscione AC, Hayes EJ. Uterine artery Doppler flow studies in obstetric practice. Am J Obstet Gynecol. (2009) 201:1216. doi: 10.1016/j.ajog.2009.03.027

26. Mo LY, Bascom PA, Ritchie K, McCowan LM, A. transmission line modelling approach to the interpretation of uterine Doppler waveforms. Ultrasound Med Biol. (1988) 14:365-76. doi: 10.1016/0301-5629(88)90072-5

27. Plasencia W, Barber MA, Alvarez EE, Segura J, Valle L, Garcia-Hernandez JA. Comparative study of transabdominal and transvaginal uterine artery Doppler pulsatility indices at 11-13 + 6 weeks. Hypertens Pregnancy. (2011) 30:414-20. doi: 10.3109/10641955.2010.506232

28. Dimitriadis E, Menkhorst E, Saito S, Kutteh WH, Brosens JJ. Recurrent pregnancy loss. Nat Rev Dis Primers. (2020) 6:98. doi: 10.1038/s41572-020-00228-z

29. Van den Berg MM, Vissenberg R, Goddijn M. Recurrent miscarriage clinics. Obstet Gynecol Clin North Am. (2014) 41:145-55. doi: 10.1016/j.ogc.2013.10.010

30. Yang X, Yang E, Wang WJ, He Q, Jubiz G, Katukurundage D, et al. Decreased HLA-C1 alleles in couples of KIR2DL2 positive women with recurrent pregnancy loss. J Reprod Immunol. (2020) 142:103186. doi: 10.1016/j.jri.2020.103186

31. Evaluation and treatment of recurrent pregnancy loss: a committee opinion. Fertil Steril. (2012) 98:1103-11. doi: 10.1016/j.fertnstert.2012.06.048

32. Kwak-Kim J, Park JC, Ahn HK, Kim JW, Gilman-Sachs A. Immunological modes of pregnancy loss. Am J Reprod Immunol. (2010) 63:61123. doi: 10.1111/j.1600-0897.2010.00847.x

33. Ferreira AM, Pires CR, Moron AF, Araujo Júnior E, Traina E, Mattar R. Doppler assessment of uterine blood flow in recurrent pregnancy loss. Int J Gynaecol Obstet. (2007) 98:115-9. doi: 10.1016/j.ijgo.2007.05.006

34. Jirous J, Diejomaoh ME, Al-Abdulhadi F, Boland MH, Nazar M, A. comparison of the uterine and intraovarian arterial flows in non-pregnant women having a history of recurrent spontaneous miscarriage associated with antiphospholipid syndrome. Arch Gynecol Obstet. (2004) 270:748. doi: 10.1007/s00404-003-0510-0

35. Lazzarin N, Vaquero E, Exacoustos C, Romanini E, Amadio A, Arduini D. Midluteal phase Doppler assessment of uterine artery blood flow in non-pregnant women having a history of recurrent spontaneous abortions: correlation to different etiologies. Fertil Steril. (2007) 87:13837. doi: $10.1016 /$ j.fertnstert.2006.11.049

36. Abdel-Razik M, El-Berry S, Mostafa A. The effects of nitric oxide donors on uterine artery and sub-endometrial blood flow in patients with unexplained recurrent abortion. J Reprod Infertil. (2014) 15:142-6

37. Özkan MB, Ozyazici E, Emiroglu B, Özkara E. Can we measure the spiral and uterine artery blood flow by real-time sonography and Doppler indices to predict spontaneous miscarriage in a normal-risk population? Australas J Ultrasound Med. (2015) 18:60-6. doi: 10.1002/j.2205-0140.2015.tb00043.x

38. El-mashad AI, Mohamed MA, Farag MA, Ahmad MK, Ismail Y. Role of uterine artery Doppler velocimetry indices and plasma adrenomedullin level in women with unexplained recurrent pregnancy loss. J Obstet Gynaecol Res. (2011) 37:51-7. doi: 10.1111/j.1447-0756.2010.01318.x

39. Molazadeh M, Karimzadeh H, Azizi MR. Prevalence and clinical significance of antinuclear antibodies in Iranian women with unexplained recurrent miscarriage. Iran J Reprod Med. (2014) 12:221-6

40. Ying Y, Zhong YP, Zhou CQ, Xu YW, Ding CH, Wang Q, et al. A further exploration of the impact of antinuclear antibodies on in vitro fertilization-embryo transfer outcome. Am J Reprod Immunol. (2013) 70:221-9. doi: 10.1111/aji.12111

41. Pietropolli A, Bruno V, Capogna MV, Bernardini S, Piccione E, Ticconi C. Uterine blood flow indices, antinuclear autoantibodies and unexplained recurrent miscarriage. Obstet Gynecol Sci. (2015) 58:453-60. doi: 10.5468/ogs.2015.58.6.453 
42. Nakatsuka M, Habara T, Noguchi S, Konishi H, Kudo T. Impaired uterine arterial blood flow in pregnant women with recurrent pregnancy loss. $J$ Ultrasound Med. (2003) 22:27-31. doi: 10.7863/jum.2003.22.1.27

43. Miwa I, Tamura H, Takasaki A, Yamagata Y, Shimamura K, Sugino N. Pathophysiologic features of "thin" endometrium. Fertil Steril. (2009) 91:998-1004. doi: 10.1016/j.fertnstert.2008.01.029

44. Tamura H, Miwa I, Taniguchi K, Maekawa R, Asada H, Taketani T, et al. Different changes in resistance index between uterine artery and uterine radial artery during early pregnancy. Hum Reprod. (2008) 23:2859. doi: 10.1093/humrep/dem375

45. Koo HS, Kwak-Kim J, Yi HJ, Ahn HK, Park CW, Cha SH, et al. Resistance of uterine radial artery blood flow was correlated with peripheral blood NK cell fraction and improved with low molecular weight heparin therapy in women with unexplained recurrent pregnancy loss. Am J Reprod Immunol. (2015) 73:175-84. doi: 10.1111/aji.12316

46. Duley L. The global impact of pre-eclampsia and eclampsia. Semin Perinatol. (2009) 33:130-7. doi: 10.1053/j.semperi.2009.02.010

47. Wu P, Haththotuwa R, Kwok CS, Babu A, Kotronias RA, Rushton $\mathrm{C}$, et al. Preeclampsia and future cardiovascular health: a systematic review and meta-analysis. Circ Cardiovasc Qual Outcomes. (2017) 10:3497. doi: 10.1161/circoutcomes.116.003497

48. Figueras F, Gratacos E. An integrated approach to fetal growth restriction. Best Pract Res Clin Obstet Gynaecol. (2017) 38:48-58. doi: 10.1016/j.bpobgyn.2016.10.006

49. Gordijn SJ, Beune IM, Thilaganathan B, Papageorghiou A, Baschat $\mathrm{AA}$, Baker $\mathrm{PN}$, et al. Consensus definition of fetal growth restriction: a Delphi procedure. Ultrasound Obstet Gynecol. (2016) 48:333-9. doi: 10.1002/uog.15884

50. Verlohren S, Galindo A, Schlembach D, Zeisler H, Herraiz I, Moertl MG, et al. An automated method for the determination of the sFlt-1/PIGF ratio in the assessment of preeclampsia. Am J Obstet Gynecol. (2010) 202:161. doi: 10.1016/j.ajog.2009.09.016

51. Honarjoo M, Kohan S, Zarean E, Tarrahi MJ. Assessment of $\beta$ human-derived chorionic gonadotrophic hormone ( $\beta$ hCG) and pregnancyassociated plasma protein A (PAPP-A) levels as predictive factors of preeclampsia in the first trimester among Iranian women: a cohort study. BMC Pregnancy Childbirth. (2019) 19:464. doi: 10.1186/s12884-019-2526-x

52. Yapa HM, Bärnighausen T. Implementation science in resourcepoor countries and communities. Implement Sci. (2018) 13:154. doi: 10.1186/s13012-018-0847-1

53. Kurdi W, Campbell S, Aquilina J, England P, Harrington K. The role of color Doppler imaging of the uterine arteries at 20 weeks' gestation in stratifying antenatal care. Ultrasound Obstet Gynecol. (1998) 12:33945. doi: 10.1046/j.1469-0705.1998.12050339.x

54. Papageorghiou AT Yu CK, Bindra R, Pandis G, Nicolaides KH. Multicenter screening for pre-eclampsia and fetal growth restriction by transvaginal uterine artery Doppler at 23 weeks of gestation. Ultrasound Obstet Gynecol. (2001) 18:441-9. doi: 10.1046/j.0960-7692.2001.00572.x

55. Martin AM, Bindra R, Curcio P, Cicero S, Nicolaides KH. Screening for pre-eclampsia and fetal growth restriction by uterine artery Doppler at 11-14 weeks of gestation. Ultrasound Obstet Gynecol. (2001) 18:5836. doi: 10.1046/j.0960-7692.2001.00594.x

56. Phupong V, Dejthevaporn T, Tanawattanacharoen S, Manotaya S, Tannirandorn Y, Charoenvidhya D. Predicting the risk of preeclampsia and small for gestational age infants by uterine artery Doppler in low-risk women. Arch Gynecol Obstet. (2003) 268:158-61. doi: 10.1007/s00404-002-0361-0

57. Vainio M, Kujansuu E, Koivisto AM, Mäenpää J. Bilateral notching of uterine arteries at 12-14 weeks of gestation for prediction of hypertensive disorders of pregnancy. Acta Obstet Gynecol Scand. (2005) 84:10627. doi: 10.1111/j.0001-6349.2005.00889.x

58. Gómez O, Martínez JM, Figueras F, Del Río M, Borobio V, Puerto B, et al. Uterine artery Doppler at 11-14 weeks of gestation to screen for hypertensive disorders and associated complications in an unselected population. Ultrasound Obstet Gynecol. (2005) 26:490-4. doi: 10.1002/uog. 1976

59. Palma-Dias RS, Fonseca MM, Brietzke E, Fritsch A, Schlatter D, Maurmann $\mathrm{CB}$, et al. Screening for placental insufficiency by transvaginal uterine artery
Doppler at 22-24 weeks of gestation. Fetal Diagn Ther. (2008) 24:4629. doi: 10.1159/000178141

60. Melchiorre K, Wormald B, Leslie K, Bhide A, Thilaganathan B. Firsttrimester uterine artery Doppler indices in term and preterm pre-eclampsia. Ultrasound Obstet Gynecol. (2008) 32:133-7. doi: 10.1002/uog.5400

61. Plasencia W, Maiz N, Poon L, Yu C, Nicolaides KH. Uterine artery Doppler at $11+0$ to $13+6$ weeks and $21+0$ to $24+6$ weeks in the prediction of pre-eclampsia. Ultrasound Obstet Gynecol. (2008) 32:13846. doi: 10.1002/uog.5402

62. Melchiorre K, Leslie K, Prefumo F, Bhide A, Thilaganathan B. First-trimester uterine artery Doppler indices in the prediction of small-for-gestational age pregnancy and intrauterine growth restriction. Ultrasound Obstet Gynecol. (2009) 33:524-9. doi: 10.1002/uog.6368

63. Ghi T, Contro E, Youssef A, Giorgetta F, Farina A, Pilu G, et al. Persistence of increased uterine artery resistance in the third trimester and pregnancy outcome. Ultrasound Obstet Gynecol. (2010) 36:57781. doi: $10.1002 /$ uog.7602

64. Maroni E, Youssef A, Arcangeli T, Nanni M, De Musso F, Contro $\mathrm{E}$, et al. Increased uterine artery pulsatility index at 34 weeks and outcome of pregnancy. Ultrasound Obstet Gynecol. (2011) 38:3959. doi: 10.1002/uog.8966

65. Lai J, Poon LC, Pinas A, Bakalis S, Nicolaides KH. Uterine artery Doppler at 30-33 weeks' gestation in the prediction of preeclampsia. Fetal Diagn Ther. (2013) 33:156-63. doi: 10.1159/000343665

66. Barati M, Shahbazian N, Ahmadi L, Masihi S. Diagnostic evaluation of uterine artery Doppler sonography for the prediction of adverse pregnancy outcomes. J Res Med Sci. (2014) 19:515-9.

67. Parry S, Sciscione A, Haas DM, Grobman WA, Iams JD, Mercer BM, et al. Role of early second-trimester uterine artery Doppler screening to predict small-for-gestational-age babies in nulliparous women. Am J Obstet Gynecol. (2017). 217:594. doi: 10.1016/j.ajog.2017.06.013

68. Prakansamut N, Phupong V. Serum SHARP1 and uterine artery Doppler for the prediction of preeclampsia. Sci Rep. (2019) 9:12266. doi: 10.1038/s41598-019-48727-8

69. Običan SG, Odibo L, Tuuli MG, Rodriguez A, Odibo AO. Third trimester uterine artery Doppler indices as predictors of preeclampsia and neonatal small for gestational age. J Matern Fetal Neonatal Med. (2020) 33:34849. doi: 10.1080/14767058.2019.1575804

70. Oancea M, Grigore M, Ciortea R, Diculescu D, Bodean D, Bucuri C, et al. Uterine artery doppler ultrasonography for first trimester prediction of preeclampsia in individuals at risk from low-resource settings. Medicina. (2020) 56:428. doi: 10.3390/medicina56090428

71. Poon LC, Stratieva V, Piras S, Piri S, Nicolaides KH. Hypertensive disorders in pregnancy: combined screening by uterine artery Doppler, blood pressure and serum PAPP-A at 11-13 weeks. Prenat Diagn. (2010) 30:216-23. doi: 10.1002/pd.2440

72. Poon LC, Nicolaides KH. Early prediction of preeclampsia. Obstet Gynecol Int. (2014) 2014:297397. doi: 10.1155/2014/297397

73. Matevosyan NR. Predictive accuracy of the first trimester Doppler scan: a meta-study. Wien Med Wochenschr. (2015) 165:199-209. doi: 10.1007/s10354-015-0358-5

74. Chan FY, Pun TC, Lam C, Khoo J, Lee CP, Lam YH. Pregnancy screening by uterine artery Doppler velocimetry-which criterion performs best? Obstet Gynecol. (1995) 85:596-602. doi: 10.1016/0029-7844(95)00006-d

75. Harrington K, Fayyad A, Thakur V, Aquilina J. The value of uterine artery Doppler in the prediction of uteroplacental complications in multiparous women. Ultrasound Obstet Gynecol. (2004) 23:50-5. doi: 10.1002/uog.932

76. Coleman MA, McCowan LM, North RA. Mid-trimester uterine artery Doppler screening as a predictor of adverse pregnancy outcome in high-risk women. Ultrasound Obstet Gynecol. (2000) 15:7-12. doi: 10.1046/j.1469-0705.2000.00014.x

77. Lees C, Parra M, Missfelder-Lobos H, Morgans A, Fletcher O, Nicolaides $\mathrm{KH}$. Individualized risk assessment for adverse pregnancy outcome by uterine artery Doppler at 23 weeks. Obstet Gynecol. (2001) 98:36973. doi: 10.1016/s0029-7844(01)01474-0

78. Harrington K, Goldfrad C, Carpenter RG, Campbell S. Transvaginal uterine and umbilical artery Doppler examination of 12-16 weeks and the subsequent development of pre-eclampsia and 
intrauterine growth retardation. Ultrasound Obstet Gynecol. (1997) 9:94-100. doi: 10.1046/j.1469-0705.1997.09020094.x

79. Ratiu D, Hide-Moser K, Morgenstern B, Gottschalk I, Eichler C, Ludwig S, et al. Doppler indices and notching assessment of uterine artery between the 19th and 22nd week of pregnancy in the prediction of pregnancy outcome. In Vivo. (2019) 33:2199-204. doi: 10.21873/invivo.11722

80. Espinoza J, Kusanovic JP, Bahado-Singh R, Gervasi MT, Romero R, Lee W, et al. Should bilateral uterine artery notching be used in the risk assessment for preeclampsia, small-for-gestational-age, and gestational hypertension? J Ultrasound Med. (2010) 29:1103-15. doi: 10.7863/jum.2010.29.7.1103

81. Brodszki J, Länne T, Stale H, Batra S, Marsál K. Altered vascular function in healthy normotensive pregnant women with bilateral uterine artery notches. Bjog. (2002) 109:546-52. doi: 10.1111/j.1471-0528.2002.01315.x

82. Takahashi K, Ohkuchi A, Hirashima C, Matsubara S, Suzuki M. Establishing reference values for mean notch depth index, pulsatility index and resistance index in the uterine artery at 16-23 weeks' gestation. J Obstet Gynaecol Res. (2012) 38:1275-85. doi: 10.1111/j.1447-0756.2012.01864.x

83. Becker R, Vonk R, Vollert W, Entezami M. Doppler sonography of uterine arteries at 20-23 weeks: risk assessment of adverse pregnancy outcome by quantification of impedance and notch. J Perinat Med. (2002) 30:38894. doi: $10.1515 /$ jpm. 2002.060

84. Becker R, Vonk R. Doppler sonography of uterine arteries at 20-23 weeks: depth of notch gives information on probability of adverse pregnancy outcome and degree of fetal growth restriction in a low-risk population. Fetal Diagn Ther. (2010) 27:78-86. doi: 10.1159/000274377

85. Familiari A, Bhide A, Morlando M, Scala C, Khalil A, Thilaganathan B. Mid-pregnancy fetal biometry, uterine artery Doppler indices and maternal demographic characteristics: role in prediction of small-for-gestational-age birth. Acta Obstet Gynecol Scand. (2016) 95:238-44. doi: 10.1111/aogs.12804

86. Cnossen JS, Morris RK. ter Riet G, Mol BW, van der Post JA, Coomarasamy A, et al. Use of uterine artery Doppler ultrasonography to predict pre-eclampsia and intrauterine growth restriction: a systematic review and bivariable meta-analysis. CMAJ. (2008) 178:701-11. doi: 10.1503/cmaj.070430

87. Hafner E, Metzenbauer M, Höfinger D, Stonek F, Schuchter K, Waldhör $\mathrm{T}$, et al. Comparison between three-dimensional placental volume at 12 weeks and uterine artery impedance/notching at 22 weeks in screening for pregnancy-induced hypertension, pre-eclampsia and fetal growth restriction in a low-risk population. Ultrasound Obstet Gynecol. (2006) 27:6527. doi: $10.1002 /$ uog. 2641

88. Vergani P, Roncaglia N, Andreotti C, Arreghini A, Teruzzi M, Pezzullo JC, et al. Prognostic value of uterine artery Doppler velocimetry in growthrestricted fetuses delivered near term. Am J Obstet Gynecol. (2002) 187:9326. doi: $10.1067 / \mathrm{mob} .2002 .127137$

89. Severi FM, Bocchi C, Visentin A, Falco P, Cobellis L, Florio P, et al. Uterine and fetal cerebral Doppler predict the outcome of third-trimester small-for-gestational age fetuses with normal umbilical artery Doppler. Ultrasound Obstet Gynecol. (2002) 19:225-8. doi: 10.1046/j.1469-0705.2002. 00652.x

90. Li H, Gudnason H, Olofsson P, Dubiel M, Gudmundsson S. Increased uterine artery vascular impedance is related to adverse outcome of pregnancy but is present in only one-third of late third-trimester pre-eclamptic women. Ultrasound Obstet Gynecol. (2005) 25:459-63. doi: 10.1002/uog.1895

91. Ghosh GS, Gudmundsson S. Uterine and umbilical artery Doppler are comparable in predicting perinatal outcome of growth-restricted fetuses. BJOG. (2009) 116:424-30. doi: 10.1111/j.1471-0528.2008.02057.x

92. Shwarzman P, Waintraub AY, Frieger M, Bashiri A, Mazor M, Hershkovitz R. Third-trimester abnormal uterine artery Doppler findings are associated with adverse pregnancy outcomes. J Ultrasound Med. (2013) 32:210713. doi: $10.7863 /$ ultra.32.12.2107

93. Figueras F, Savchev S, Triunfo S, Crovetto F, Gratacos E. An integrated model with classification criteria to predict small-for-gestational-age fetuses at risk of adverse perinatal outcome. Ultrasound Obstet Gynecol. (2015) 45:279-85. doi: 10.1002/uog.14714

94. Valiño N, Giunta G, Gallo DM, Akolekar R, Nicolaides KH. Uterine artery pulsatility index at $30-34$ weeks' gestation in the prediction of adverse perinatal outcome. Ultrasound Obstet Gynecol. (2016) 47:30815. doi: $10.1002 /$ uog. 14898
95. Khalil A, Morales-Roselló J, Townsend R, Morlando M, Papageorghiou A, Bhide A, et al. Value of third-trimester cerebroplacental ratio and uterine artery Doppler indices as predictors of stillbirth and perinatal loss. Ultrasound Obstet Gynecol. (2016) 47:74-80. doi: 10.1002/uog.15729

96. Ghi T, Youssef A, Piva M, Contro E, Segata M, Guasina F, et al. The prognostic role of uterine artery Doppler studies in patients with late-onset preeclampsia. Am J Obstet Gynecol. (2009) 201:36. doi: 10.1016/j.ajog.2009.02.024

97. Tsiakkas A, Saiid Y, Wright A, Wright D, Nicolaides KH. Competing risks model in screening for preeclampsia by maternal factors and biomarkers at 30-34 weeks' gestation. Am J Obstet Gynecol. (2016) 215:87. doi: 10.1016/j.ajog.2016.02.016

98. Tayyar A, Guerra L, Wright A, Wright D, Nicolaides KH. Uterine artery pulsatility index in the three trimesters of pregnancy: effects of maternal characteristics and medical history. Ultrasound Obstet Gynecol. (2015) 45:689-97. doi: 10.1002/uog.14789

99. Khalil A, Garcia-Mandujano R, Maiz N, Elkhouli M, Nicolaides KH. Longitudinal changes in uterine artery Doppler and blood pressure and risk of pre-eclampsia. Ultrasound Obstet Gynecol. (2014) 43:5417. doi: 10.1002/uog. 13257

100. Rodríguez M, Couve-Pérez C, San Martín S, Martínez F, Lozano C, Sepúlveda-Martínez A. Perinatal outcome and placental apoptosis in patients ate-onset pre-eclampsia and abnormal uterine artery Doppler at diagnosis. Ultrasound Obstet Gynecol. (2018) 51:775-82. doi: 10.1002/uog.17515

101. Llurba E, Turan O, Kasdaglis T, Harman CR, Baschat AA. Emergence of late-onset placental dysfunction: relationship to the change in uterine artery blood flow resistance between the first and third trimesters. Am J Perinatol. (2013) 30:505-12. doi: 10.1055/s-0032-1329181

102. Collins SL, Grant D, Black RS, Vellayan M, Impey L. Abdominal pregnancy: a perfusion confusion? Placenta. (2011) 32:7935. doi: 10.1016/j.placenta.2011.07.032

103. Acácio GL. Uterine artery Doppler patterns in abdominal pregnancy. Ultrasound Obstet Gynecol. (2002) 20:1946. doi: 10.1046/j.1469-0705.2002.00769.x

104. Leslie K, Thilaganathan B. A perfusion confusion? Placenta. (2012) 33:230. doi: 10.1016/j.placenta.2011.12.011

105. Melchiorre K, Sutherland G, Sharma R, Nanni M, Thilaganathan B. Mid-gestational maternal cardiovascular profile in preterm and term pre-eclampsia: a prospective study. Bjog. (2013) 120:496-504. doi: 10.1111/1471-0528.12068

106. Thilaganathan B. Association of higher maternal blood pressure with lower infant birthweight: placental cause or cardiovascular effect?. Hypertension. (2016) 67:499-500. doi: 10.1161/hypertensionaha.115.06880

107. Parra-Saavedra M, Simeone S, Triunfo S, Crovetto F, Botet F, Nadal A, et al. Correlation between histological signs of placental underperfusion and perinatal morbidity in late-onset small-for-gestational-age fetuses. Ultrasound Obstet Gynecol. (2015) 45:149-55. doi: 10.1002/uog.13415

108. Parra-Saavedra M, Crovetto F, Triunfo S, Savchev S, Peguero A, Nadal A, et al. Association of Doppler parameters with placental signs of underperfusion in late-onset small-for-gestational-age pregnancies. Ultrasound Obstet Gynecol. (2014) 44:330-7. doi: 10.1002/uog.13358

109. Gómez O, Figueras F, Martínez JM. del Río M, Palacio M, Eixarch E, et al. Sequential changes in uterine artery blood flow pattern between the first and second trimesters of gestation in relation to pregnancy outcome ultrasound. Obstet Gynecol. (2006) 28:802-8. doi: 10.1002/uog.2814

110. Carbillon L, Uzan M, Largillière C, Perrot N, Tigaizin A, Paries J, et al. Prospective evaluation of uterine artery flow velocity waveforms at 12-14 and 22-24 weeks of gestation in relation to pregnancy outcome and birth weight. Fetal Diagn Ther. (2004) 19:381-4. doi: 10.1159/000077971

111. Binder J, Monaghan C, Thilaganathan B, Carta S, Khalil A. De-novo abnormal uteroplacental circulation in third trimester: pregnancy outcome and pathological implications. Ultrasound Obstet Gynecol. (2018) 52:605. doi: $10.1002 /$ uog. 17564

112. Poon LC, Syngelaki A, Akolekar R, Lai J, Nicolaides KH. Combined screening for preeclampsia and small for gestational age at 11-13 weeks. Fetal Diagn Ther. (2013) 33:16-27. doi: 10.1159/000341712

113. O'Gorman N, Wright D, Syngelaki A, Akolekar R, Wright A, Poon LC, et al. Competing risks model in screening for preeclampsia by maternal 
factors and biomarkers at 11-13 weeks gestation. Am J Obstet Gynecol. (2016) 214:103.. doi: 10.1016/j.ajog.2015.08.034

114. Gallo DM, Wright D, Casanova C, Campanero M, Nicolaides KH. Competing risks model in screening for preeclampsia by maternal factors and biomarkers at 19-24 weeks' gestation. Am J Obstet Gynecol. (2016) 214:619. doi: 10.1016/j.ajog.2015.11.016

115. Andrietti S, Carlucci S, Wright A, Wright D, Nicolaides KH. Repeat measurements of uterine artery pulsatility index, mean arterial pressure, and serum placental growth factor at 12, 22, and 32 weeks in prediction of pre-eclampsia. Ultrasound Obstet Gynecol. (2017) 50:2217. doi: $10.1002 /$ uog. 17403

116. Karagiannis G, Akolekar R, Sarquis R, Wright D, Nicolaides KH. Prediction of small-for-gestation neonates from biophysical and biochemical markers at 11-13 weeks. Fetal Diagn Ther. (2011) 29:148-54. doi: 10.1159/000321694

117. Pilalis A, Souka AP, Antsaklis P, Daskalakis G, Papantoniou N, Mesogitis $\mathrm{S}$, et al. Screening for pre-eclampsia and fetal growth restriction by uterine artery Doppler and PAPP-A at 11-14 weeks' gestation. Ultrasound Obstet Gynecol. (2007) 29:135-40. doi: 10.1002/uog.3881

118. Aquilina J, Thompson O, Thilaganathan B, Harrington K. Improved early prediction of pre-eclampsia by combining second-trimester maternal serum inhibin-A and uterine artery Doppler. Ultrasound Obstet Gynecol. (2001) 17:477-84. doi: 10.1046/j.1469-0705.2001.00382.x

119. Gómez-Arriaga PI, Herraiz I, López-Jiménez EA, Gómez-Montes E, Denk B, Galindo A. Uterine artery Doppler and sFlt-1/PlGF ratio: usefulness in diagnosis of pre-eclampsia. Ultrasound Obstet Gynecol. (2013) 41:5307. doi: 10.1002/uog. 12400

120. Mula R, Meler E, García S, Albaigés G, Serra B, Scazzocchio E, et al. "Screening for small-for-gestational age neonates at early third trimester in a high-risk population for preeclampsia." BMC Pregnancy Childbirth. (2020) 20:563. doi: $10.1186 / \mathrm{s} 12884-020-03167-5$

121. Frøen JF, Pinar H, Flenady V, Bahrin S, Charles A, Chauke L, et al. Causes of death and associated conditions (Codac): a utilitarian approach to the classification of perinatal deaths. BMC Pregnancy Childbirth. (2009) 9:22. doi: 10.1186/1471-2393-9-22

122. Akolekar R, Machuca M, Mendes M, Paschos V, Nicolaides KH. Prediction of stillbirth from placental growth factor at 11-13 weeks. Ultrasound Obstet Gynecol. (2016) 48:618-23. doi: 10.1002/uog.17288

123. Singh T, Leslie K, Bhide A, D'Antonio F, Thilaganathan B. Role of secondtrimester uterine artery Doppler in assessing stillbirth risk. Obstet Gynecol. (2012) 119:256-61. doi: 10.1097/AOG.0b013e318242ad81

124. Akolekar R, Tokunaka M, Ortega N, Syngelaki A, Nicolaides KH. Prediction of stillbirth from maternal factors, fetal biometry and uterine artery Doppler at 19-24 weeks. Ultrasound Obstet Gynecol. (2016) 48:62430. doi: 10.1002/uog. 17295

125. Poon LC, Volpe N, Muto B, Yu CK, Syngelaki A, Nicolaides KH. Secondtrimester uterine artery Doppler in the prediction of stillbirths. Fetal Diagn Ther. (2013) 33:28-35. doi: 10.1159/000342109

126. Smith GC Yu CK, Papageorghiou AT, Cacho AM, Nicolaides KH. Maternal uterine artery Doppler flow velocimetry and the risk of stillbirth. Obstet Gynecol. (2007) 109:144-51. doi: 10.1097/01.AOG.0000248536.94919.e3

127. Vogel JP, Chawanpaiboon S, Moller AB, Watananirun K, Bonet M, Lumbiganon P. The global epidemiology of preterm birth. Best Pract Res Clin Obstet Gynaecol. (2018) 52:3-12. doi: 10.1016/j.bpobgyn.2018.04.003

128. Kim YM, Bujold E, Chaiworapongsa T, Gomez R, Yoon BH, Thaler HT, et al. Failure of physiologic transformation of the spiral arteries in patients with preterm labor and intact membranes. Am J Obstet Gynecol. (2003) 189:1063-9. doi: 10.1067/s0002-9378(03)00838-x

129. McKelvey A, Pateman K, Balchin I, Peebles DM, Rodeck CH, David AL. Total uterine artery blood volume flow rate in nulliparous women is associated with birth weight and gestational age at delivery. Ultrasound Obstet Gynecol. (2017) 49:54-60. doi: 10.1002/uog.15917

130. Parra-Cordero M, Sepúlveda-Martínez A, Rencoret G, Valdés E, Pedraza $\mathrm{D}$, Muñoz H. Is there a role for cervical assessment and uterine artery Doppler in the first trimester of pregnancy as a screening test for spontaneous preterm delivery? Ultrasound Obstet Gynecol. (2014) 43:2916. doi: 10.1002/uog. 12465

131. Fonseca E, Yu CK, Singh $\mathrm{M}$, Papageorghiou AT, Nicolaides KH. Relationship between second-trimester uterine artery Doppler and spontaneous early preterm delivery. Ultrasound Obstet Gynecol. (2006) 27:301-5. doi: 10.1002/uog.2594

132. van Zijl MD, Koullali B, Mol BWJ, Snijders RJ, Kazemier BM, Pajkrt E. The predictive capacity of uterine artery Doppler for preterm birth-a cohort study. Acta Obstet Gynecol Scand. (2020) 99:494-502. doi: 10.1111/aogs.13770

133. Cobian-Sanchez F, Prefumo F, Bhide A, Thilaganathan B. Second-trimester uterine artery Doppler and spontaneous preterm delivery. Ultrasound Obstet Gynecol. (2004) 24:435-9. doi: 10.1002/uog.1116

134. Svirsky R, Yagel S, Ben-Ami I, Cuckle H, Klug E, Maymon R. First trimester markers of preeclampsia in twins: maternal mean arterial pressure and uterine artery Doppler pulsatility index. Prenat Diagn. (2014) 34:95660. doi: $10.1002 /$ pd.4402

135. Rizzo G, Pietrolucci ME, Aiello E, Capponi A, Arduini D. Uterine artery Doppler evaluation in twin pregnancies at $11+0$ to 13 + 6 weeks of gestation. Ultrasound Obstet Gynecol. (2014) 44:55761. doi: 10.1002/uog.13340

136. Klein K, Mailath-Pokorny M, Elhenicky M, Schmid M, Zeisler H, Worda C. Mean, lowest, and highest pulsatility index of the uterine artery and adverse pregnancy outcome in twin pregnancies. Am J Obstet Gynecol. (2011) 205:549. doi: 10.1016/j.ajog.2011.06.103

137. Rizzo G, Arduini D, Romanini C. Uterine artery Doppler velocity waveforms in twin pregnancies. Obstet Gynecol. (1993) 82:978-83.

138. Geipel A, Hennemann F, Fimmers R, Willruth A, Lato K, Gembruch U, et al. Reference ranges for Doppler assessment of uterine artery resistance and pulsatility indices in dichorionic twin pregnancies. Ultrasound Obstet Gynecol. (2011) 37:663-7. doi: 10.1002/uog.8859

139. Masini G, Tordini C, Pietrosante A, Gaini C, Di Tommaso M, Pasquini L. Prediction of pregnancy complications by second-trimester uterine artery Doppler assessment in monochorionic twins. J Clin Ultrasound. (2019) 47:399-404. doi: 10.1002/jcu.22734

140. Yu CK, Papageorghiou AT, Boli A, Cacho AM, Nicolaides KH. Screening for pre-eclampsia and fetal growth restriction in twin pregnancies at 23 weeks of gestation by transvaginal uterine artery Doppler. Ultrasound Obstet Gynecol. (2002) 20:535-40. doi: 10.1046/j.1469-0705.2002.00865.x

141. Sebire NJ. Routine uterine artery Doppler screening in twin pregnancies? Ultrasound Obstet Gynecol. (2002) 20:5324. doi: 10.1046/j.1469-0705.2002.00856.x

142. Geipel A, Berg C, Germer U, Katalinic A, Krapp M, Smrcek J, et al. Doppler assessment of the uterine circulation in the second trimester in twin pregnancies: prediction of pre-eclampsia, fetal growth restriction and birth weight discordance. Ultrasound Obstet Gynecol. (2002) 20:5415. doi: 10.1046/j.1469-0705.2002.00866.x

143. Francisco C, Wright D, Benko Z, Syngelaki A, Nicolaides KH. Competingrisks model in screening for pre-eclampsia in twin pregnancy according to maternal factors and biomarkers at 11-13 weeks' gestation. Ultrasound Obstet Gynecol. (2017) 50:589-95. doi: 10.1002/uog.17531

144. Roberge S, Nicolaides KH, Demers S, Villa P, Bujold E. Prevention of perinatal death and adverse perinatal outcome using low-dose aspirin: a meta-analysis. Ultrasound Obstet Gynecol. (2013) 41:4919. doi: $10.1002 /$ uog. 12421

145. Duley L, Meher S, Hunter KE, Seidler AL, Askie LM. Antiplatelet agents for preventing pre-eclampsia and its complications. Cochrane Database Syst Rev. (2019) 2019. doi: 10.1002/14651858.CD004659.pub3

146. Coomarasamy A, Papaioannou S, Gee H, Khan KS. Aspirin for the prevention of preeclampsia in women with abnormal uterine artery Doppler: a meta-analysis. Obstet Gynecol. (2001) 98:861-6. doi: 10.1016/s0029-7844(01)01569-1

147. Askie LM, Duley L, Henderson-Smart DJ, Stewart LA. Antiplatelet agents for prevention of pre-eclampsia: a meta-analysis of individual patient data. Lancet. (2007) 369:1791-8. doi: 10.1016/s0140-6736(07) $60712-0$

148. Roberge S, Bujold E, Nicolaides KH. Aspirin for the prevention of preterm and term preeclampsia: systematic review and meta analysis. Am J Obstet Gynecol. (2018) 218:287-93. doi: 10.1016/j.ajog.2017.11.561

149. Hale SA, Jones CW, Osol G, Schonberg A, Badger GJ, Bernstein IM. Sildenafil increases uterine blood flow in non-pregnant nulliparous women. Reprod Sci. (2010) 17:358-65. doi: 10.1177/1933719109354648 
150. Lazzarin N, Vaquero E, Exacoustos C, Bertonotti E, Romanini ME, Arduini D. Low-dose aspirin and omega-3 fatty acids improve uterine artery blood flow velocity in women with recurrent miscarriage due to impaired uterine perfusion. Fertil Steril. (2009) 92:296-300. doi: 10.1016/j.fertnstert.2008.05.045

151. Mesdaghinia E, Mohammad-Ebrahimi B, Foroozanfard F, Banafshe HR. The effect of vitamin $\mathrm{E}$ and aspirin on the uterine artery blood flow in women with recurrent abortion: a single-blind randomized controlled trial. Int $J$ Reprod Biomed. (2017) 15:635-40

152. Meads CA, Cnossen JS, Meher S, Juarez-Garcia A, ter Riet G, Duley L, et al. Methods of prediction and prevention of pre-eclampsia: systematic reviews of accuracy and effectiveness literature with economic modelling. Health Technol Assess. (2008) 12:iii-iv,. doi: 10.3310/hta12060

153. Roberts T, Henderson J, Mugford M, Bricker L, Neilson J, Garcia J. Antenatal ultrasound screening for fetal abnormalities: a systematic review of studies of cost and cost effectiveness. Bjog. (2002) 109:4456. doi: 10.1111/j.1471-0528.2002.00223.x
Conflict of Interest: The authors declare that the research was conducted in the absence of any commercial or financial relationships that could be construed as a potential conflict of interest.

Publisher's Note: All claims expressed in this article are solely those of the authors and do not necessarily represent those of their affiliated organizations, or those of the publisher, the editors and the reviewers. Any product that may be evaluated in this article, or claim that may be made by its manufacturer, is not guaranteed or endorsed by the publisher.

Copyright (C) 2022 Tian and Yang. This is an open-access article distributed under the terms of the Creative Commons Attribution License (CC BY). The use, distribution or reproduction in other forums is permitted, provided the original author(s) and the copyright owner(s) are credited and that the original publication in this journal is cited, in accordance with accepted academic practice. No use, distribution or reproduction is permitted which does not comply with these terms. 